\title{
Clonagem e expressão da glicoproteína transmembrana do retrovírus HTLV-1 em células de mamíferos
}

\author{
Cloning and transmembrane glycoprotein expression \\ of the retrovirus HTLV-1 in mammals' cells
}

\author{
Flora Cristina Lobo Penteado ${ }^{1,2}$, Luciene Medeiros $^{1}$, Maristela Delgado Orellana ${ }^{1}$, \\ Patricia Palma $^{1}$, Aparecida Maria Fontes ${ }^{1}$, Osvaldo Massaiti Takayanagui ${ }^{3}$ \\ e Dimas Tadeu Covas ${ }^{4}$
}

\begin{abstract}
RESUMO
$O$ retrovírus linfotrópico de células $T$ humanas tipo 1 é o agente etiológico da leucemia das células $T$ do adulto e da paraparesia espástica tropical/mielopatia associada ao HTLV-1. O genoma proviral é composto por 9.032 pares de bases, contendo genes estruturais e regulatórios. A glicoproteína transmembrana gp 21 é codificada pelo gene estrutural env. 0 desenvolvimento de metodologias para a expressão heteróloga de proteínas, assim como a obtenção de uma linhagem celular que expresse a gp 21 recombinante constitutivamente são os principais objetivos do trabalho. $O$ fragmento codificante da gp 21 foi amplificado por Nested-PCR e clonado no vetor pCR2.1-TOPO. Posteriormente, foi realizada a subclonagem no vetor de expressão pcDNA3.1+. A transfecção da linhagem celular de mamíferos HEK 293 foi realizada de maneira transitória e permanente. A produção da gp 21 recombinante foi confirmada por citometria de fluxo e a linhagem celular produtora será utilizada em ensaios de imunogenicidade.
\end{abstract}

Palavras-chaves: Glicoproteína transmembrana. HTLV-1. Clonagem. Expressão de proteínas.

\begin{abstract}
The retrovirus HTLV-1 is the etiological agent of the adult T-cell leukemia and HTLV-1 associated myelopathy/tropical spastic paraparesis. The proviral genome has 9,032 base pairs, showing regulatory and structural genes. The env gene encodes for the transmembrane glycoprotein gp 21. The development of methodologies for heterologous protein expression, as well as the acquisition of a cellular line that constituently expresses the recombinant, were the main goals of this work. The DNA fragment that encodes for gp 21 was amplified by nested-PCR and cloned into a pCR2.1-TOPO vector. After which, a sub-cloning was realized using the expressing vector pcDNA3.1+. The transfection of mammalian cells HEK 293 was performed transitorily and permanently. Production of the recombinant gp 21 was confirmed by flux cytometry experiments and the cell line producing protein will be used in immunogenicity assays.
\end{abstract}

Key-words: Transmembrane glycoprotein. HTLV-1. Cloning. Protein expression.

0 vírus linfotrópico de células T humanas tipo 1 (HTLV-1) é considerado 0 agente causador da leucemia/linfoma de células $\mathrm{T}$ do adulto (ATLL) ${ }^{16} \mathrm{e}$ da paraparesia espástica tropical (TSP), também conhecida como mielopatia associada ao HTLV-1 (HAM $)^{6}$. Sua transmissão se dá por contato sexual, por transfusão de sangue e de seus componentes celulares, entre usuários de drogas injetáveis e, principlamente, via amamentação. A célula alvo ao ser infectada tem suas vias de ativação e morte celular alteradas pela incorporação do material genético do vírus, passando a produzir as proteínas virais. 0 genoma proviral do retrovírus HTLV-1 é composto por $9.032 \mathrm{pb}^{15}$ e contém genes estruturais e regulatórios. 0 gene estrutural env codifica as duas glicoproteínas que constituem o envelope viral. 0 envelope do HTLV-1 é o primeiro elemento a interagir com a célula-alvo e desempenha um papel crucial no processo de infecção pois permite a entrada do retrovírus na célula. As glicoproteínas

\footnotetext{
1. Laboratório de Pesquisa do Centro Regional de Hemoterapia do Hospital das Clinicas da Faculdade de Medicina de Ribeirão Preto da Universidade de São Paulo, Ribeirão Preto, SP, Brasil. 2. Departamento de Análises Clínicas da Faculdade de Ciências Farmacêuticas Júlio de Mesquita Filho da Universidade Estadual Paulista, Araraquara, SP, Brasil. 3. Departamento de Neurologia da Faculdade de Medicina de Ribeirão Preto da Universidade de São Paulo, Ribeirão Preto, SP, Brasil. 4. Departamento de Clinica Medica da Faculdade de Medicina de Ribeirão Preto da Universidade de São Paulo, Ribeirão Preto, SP, Brasil.

Endereço para correspondência: Dra Flora Cristina Lobo Penteado. Centro Regional de Hemoterapia do HCFMRP/Hemocentro de Ribeirão Preto. R. Tenente Catão Roxo 2501, 14051-140 Ribeirão Preto , SP, Brasil.

Tel: 5516 2101-9300, Fax: 5516 2101-9309

e-mail: floralobo@pegasus.fmrp.usp.br

Recebido para publicação em 5/2/2004

Aceito em 25/1/2006
} 
são sintetizadas no retículo endoplasmático inicialmente como uma poliproteína precursora: a gp 61. Posteriormente, essa poliproteína é levada ao complexo de Golgi onde é glicosilada e clivada pela ação de uma protease celular, gerando duas subunidades. A primeira é a glicoproteína de superfície (gp 46) responsável pela ligação do retrovírus ao receptor da célula alvo, e a segunda é a glicoproteína transmembrana (gp 21) responsável pela fusão do envelope viral com a membrana da célula-alvo ${ }^{13}$.

As glicoproteínas e seus fragmentos já foram expressados em bactérias ${ }^{17}$, em leveduras ${ }^{10}$, em células de insetos ${ }^{14}$ e em células de mamíferos ${ }^{2}$. Além de usarem diferentes sistemas de expressão, estes trabalhos também diferem quanto a utilização dos produtos recombinantes; as glicoproteínas do envelope do HTLV-1 podem ser incorporadas às reações bioquímicas in vitro, com o objetivo de estudar a formação de sincícios e a entrada do vírus nas células alvo ${ }^{4}$, podem ser utilizadas no diagnóstico da infecção pelo HTLV- $1^{11}$ ou podem ser utilizadas em protocolos de imunização experimental de animais, com o objetivo de produzir uma vacina recombinante contra o vírus 9.

0 objetivo do trabalho é a expressão in vitro da gp 21 do envelope do HTLV-1 em células de mamíferos. A obtenção de uma linhagem celular que expresse constitutivamente a proteína recombinante será de grande utilidade para a realização de ensaios de imunogenicidade e no diagnóstico da infecção pelo HTLV-1.

\section{MATERIAL E MÉTODOS}

Isolamento, amplificação e preparação do fragmento referente a gp 21. 0 fragmento codificante da gp 21 foi amplificado por Nested-PCR, a partir do DNA proviral, com a utilização dos primers 5'-CCTGTTCCCACCCTAGGATCC-3' e 5'-GAAGTTGCTGCAGGAGAAGGAG-3' na primeira reação, e 5'-GAATTCCATGGGAGCCGGAGTGGCTGGC-3' e 5'-GCGGCCGCTTACAGGGATGACTCAGGTTTTATAAG-3' na seunda reação. A sequiência de nucleotídeos utilizada para o desenho dos primers foi a do protótipo ATK-1, depositada no GenBank sob o número de acesso J02029, referente ao genoma completo do HTLV-1. 0 par de primers utilizado na segunda reação foi responsável pela adição das seqüências codificantes dos sítios de restrição das enzimas EcoRI na região terminal 5' e NotI na região terminal 3' do fragmento amplificado. 0 produto da PCR foi submetido à extração com fenol - clorofórmio, seguida de precipitação com acetato de sódio 2M. O DNA precipitado foi diluído com 40uL de água estéril.

Clonagem e subclonagem do fragmento de interesse em vetores plasmidiais. 0 fragmento codificante da gp 21 foi clonado no vetor pCR2.1TOPO (Invitrogen, São Paulo, Brazil) conforme as instruções do fabricante. Bactérias Escherichia coli da linhagem DH5a (Clontech, Heidelberg, Germany) competentes foram preparadas e transformadas com o vetor recombinante pelo método do cloreto de cálcio gelado por meio do choque térmico ${ }^{12}$, de acordo com protocolos já descritos ${ }^{8}$. A cultura foi submetida à minipreparação de plasmídeo, realizada com a utilização do kit QIAprep Spin Miniprep Kit (50) (Qiagem, Hilden, Germany), segundo as instruções do fabricante. 0 fragmento codificante da gp 21 contido no vetor recombinante foi digerido usando as enzimas de restrição EcoRI e NotI na mesma reação, que foi processada a $37^{\circ} \mathrm{C}$ durante 3 horas. 0 fragmento liberado foi purificado do gel de agarose com a utilização do QUIAEX II Gel extraction kit (Qiagem, Hilden, Germany), conforme as instruções do fabricante e, posteriormente, foi clonado no vetor de expressão em células de mamíferos pcDNA3.1+ (Invitrogen, São Paulo, Brazil). 0 vetor de expressão foi primeiramente linearizado com as enzimas de restrição EcoRI e NotI. Após a purificação por meio da extração com fenol-clorofórmio, a desfosforilação foi realizada com a utilização da enzima fostatase alcalina proveniente de camarão, Shrimp Alkaline Phosphatase (SAP) (USB Corporation, Cleaveland, USA). A reação foi conduzida a $37^{\circ} \mathrm{C}$ durante 1 hora. A enzima foi desativada por incubação a $65^{\circ} \mathrm{C}$, durante 15 minutos. A ligação do vetor com o fragmento previamente preparado foi realizada com a utilização de da enzima T4 DNA ligase (Invitrogen, São Paulo, Brazil), conforme as instruções do fabricante. Bactérias Escherichia coli da linhagem DH5a competentes foram preparadas e transformadas com 0 vetor recombinante, conforme descrito neste mesmo item.

Seqüenciamento do fragmento inserido no vetor recombinante. Para o sequienciamento foi utilizado o ABI Prism Big Dye Terminator Cycle Sequencing Ready Reaction kit (Applied Biosystems, Foster City, USA). 0 protocolo da reação foi conduzido conforme as especificações do fabricante. Foram feitas duas reações: a primeira com o primer universal $\mathrm{T} 7$ sense e a segunda com o primer universal BGH anti-sense. Os produtos das reações foram submetidos à precipitação com acetato de potássio 3M e etanol absoluto. A eletroforese foi conduzida no aparelho ABI Prism 377 DNA Sequencer (Applied Biossytems, Foster City, USA), usando gel de poliacrilamida a $4 \%$, com $6 \mathrm{M}$ de uréia, a $1.500 \mathrm{~V}$, temperatura de $51^{\circ} \mathrm{C}$, durante 6 horas. 0 s eletroferogramas obtidos foram analisados por meio do software ABI Analysis Data Collection e posteriormente convertidos em sequiências de nucleotídeos por meio do software DNA Sequencing Analysis Software Versão 3.3. A montagem das seqüências consenso foi realizada pelo software Sequencher versão 4.05 (Gene Codes Corp, Ann Arbor, USA).

Transfecção de células de mamíferos com o vetor recombinante. As células da linhagem HEK $293^{7}$ foram utilizadas para a expressão da gp 21 e encontram-se depositadas no American Type Culture Collection (ATCC) sob o número de acesso CRL-1573. A transfecção transitória foi realizada por meio da técnica de lipofecção (tranfecção por lipossomos) ${ }^{5}$ com a utilização do LipofectAMINE Reagent (Invitrogen, São Paulo, Brazil), conforme as instruções do fabricante. Passadas 48 horas, as culturas foram coletadas pela adição da solução de tripsina $(0,25 \%$ (v/v) tripsina, 1mM EDTA.4Na) e lavadas duas vezes com tampão PBS. A transfecção permanente foi realizada por meio da técnica de eletroporaçãa ${ }^{3}$. Às cubetas foram adicionados $2,0 \times 10^{7}$ células e 15ug de DNA. A eletroporação foi processada a 1,2 Kv, 200 ohms e 10uF. Após 10 dias de tratamento da cultura com $800 \mathrm{ug} / \mathrm{mL}$ do antibiótico geneticina G418, observou-se o 
aparecimento de clones isolados que foram coletados para a expansão. Culturas semiconfluentes foram coletadas e utilizadas para a análise.

Análise da expressão do RNAm codificante da glicoproteína transmembrana. A extração do RNA total das células transfectadas foi feita com utilização do RNAsy Mini Kit (Qiagem, Hilden, Germany) de acordo com as instruções do fabricante. O RNA extraído foi utilizado na PCR como template para controle da contaminação com DNA genômico. Os primers

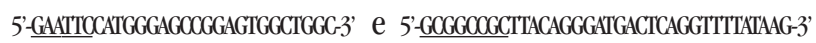
foram utilizados. A análise da expressão do RNAm foi realizada por RT-PCR. 0 cDNA foi produzido com o primer anti-sense 5'-GCGGCCGCTTACAGGGATGACTCAGGTTTTATAAG-3' por meio da utilização do kit Superscript II (Invitrogen, São Paulo, Brazil), conforme as instruções do fabricante. A PCR foi conduzida conforme já descrito neste item.

Análise da expressão da glicoproteína transmembrana recombinante. As células tranfectadas foram analisadas quanto a produção da gp 21 recombinante pela técnica de citometria de fluxo. Foram utilizadas $1 \times 10^{6}$ células de cada amostra para o experimento. 0 sedimento celular foi ressuspendido com uma solução fixadora e permeabilizadora (paraformaldeído 2\% (m/v), EGTA 50mM, e Triton X-100 0,3\% (v/v) em tampão PBS), que agiu a $37^{\circ} \mathrm{C}$ durante 10 minutos. Após a lavagem com tampão PBS, as células foram submetidas à incubação com a solução de bloqueio (albumina de soro bovino 2\% (m/v), soro de cabra $5 \%$ (v/v) em tampão PBS) a $37^{\circ} \mathrm{C}$ durante 1 hora. A marcação com o anticorpo primário monoclonal anti gp 21 de HTLV-1, produzido em camundongo (NEN Life Science Products, Boston, USA) (diluído 1:100 em solução de bloqueio), foi realizada também a $37^{\circ} \mathrm{C}$ durante 1 hora. Posteriormente, as células foram lavadas com tampão PBS e o anticorpo secundário anti-IgG de camundongo conjugado com FITC (GAM - Goat antimouse IgG FITC) (Becton Dickinson, Franklin Lakes, USA) foi adicionado, agindo por 15 minutos a temperatura ambiente sob o abrigo da luz. Após duas etapas de lavagem com tampão PBS as células foram analisadas pelo software Cell Quest no aparelho FAC Sort (Becton Dickinson, Franklin Lakes, USA). Como controle positivo foram utilizadas células da linhagem
MT-2, que possuem o genoma do HTLV-1 inserido em seu material genético. Para o controle negativo da produção da proteína recombinante foram utilizadas células HEK 293 não transfectadas.

\section{RESULTADOS}

0 fragmento gênico correspondente à região codificante da gp 21 foi amplificado por Nested-PCR, inserido no vetor de clonagem pCR2.1TOPO e subclonado no vetor de expressão pcDNA3.1+, com a utilização das enzimas de restrição EcoRI e NotI. A presença do fragmento codificante da gp 21 no vetor de recombinante foi confirmada por meio do seqüenciamento de nucleotídeos. A Figura 1 mostra 0 eletroferograma que representa parte da seqüência obtida quando utilizado o primer T7 sense, indicando a localização do códon iniciador da tradução.

0 vetor recombinante, depois de confirmado, foi inserido em células de mamíferos da linhagem HEK 293. A transfecção transitória foi realizada e após 48 horas de cultivo com meio de cultura apropriado, as células foram coletadas para as análises. Clones isolados foram observados na transfecção permanente após 10 dias de tratamento das células com 0 antibiótico. Depois de isolados e expandidos, os clones foram novamente coletados para as análises. O RT-PCR foi realizado e um fragmento de $506 \mathrm{pb}$ foi amplificado (tamanho aproximado da gp 21 contendo as seqüências codificantes dos sítios de restrição para as enzimas EcoRI e NotI) indicando a presença do RNAm codificante da gp 21, como mostra a Figura 2. A expressão transitória do RNAm codificante da gp 21 não foi observada.

As células tranfectadas foram analisadas também quanto a produção da proteína recombinante, por meio da técnica de citometria de fluxo. Primeiramente, foram analisadas células da linhagem MT-2 (que possuem o genoma do HTLV-1 inserido em seu material genético) para o controle positivo da produção da gp 21. Células da linhagem HEK 293 não transfectadas foram utilizadas como controle negativo. Os resultados obtidos com as amostras da transfecção permanente e transitória, respectivamente, se encontram representados no gráfico da Figura 3; 64\% das células da cultura mista e $48 \%$ das células do clone isolado apresentaram fluorescência, indicando a expressão da proteína recombinante.

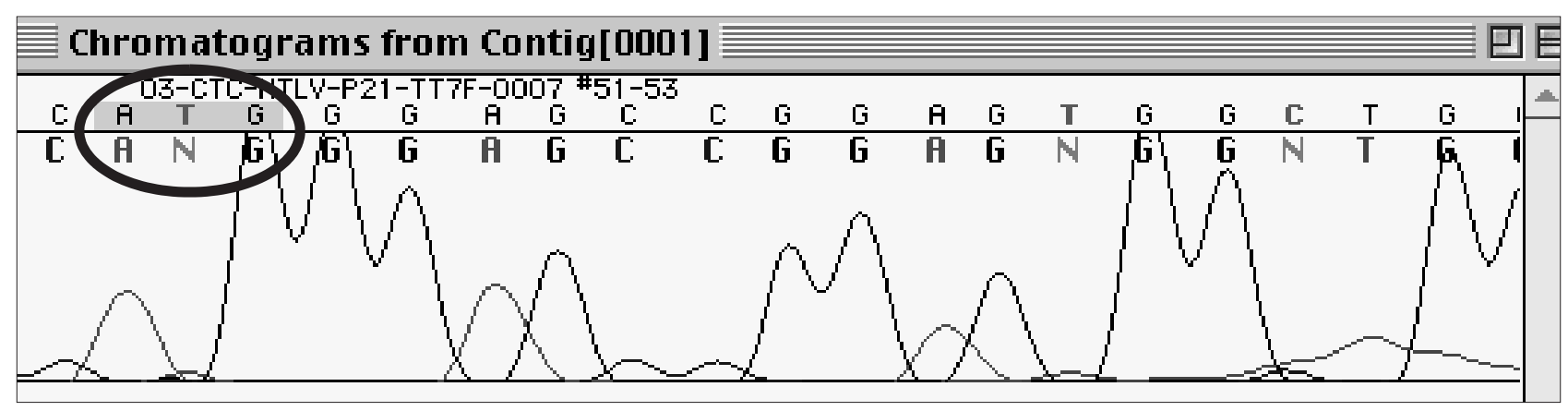

Figura 1 - Eletroferograma representando parte da seqüência obtida por meio do seqüenciamento do fragmento inserido no vetor recombinante pcDNAgp21HTLV-1 com o primer universal $T 7$ sense. 0 códon iniciador da tradução, referente ao início da gp 21 , encontra-se em destaque. 


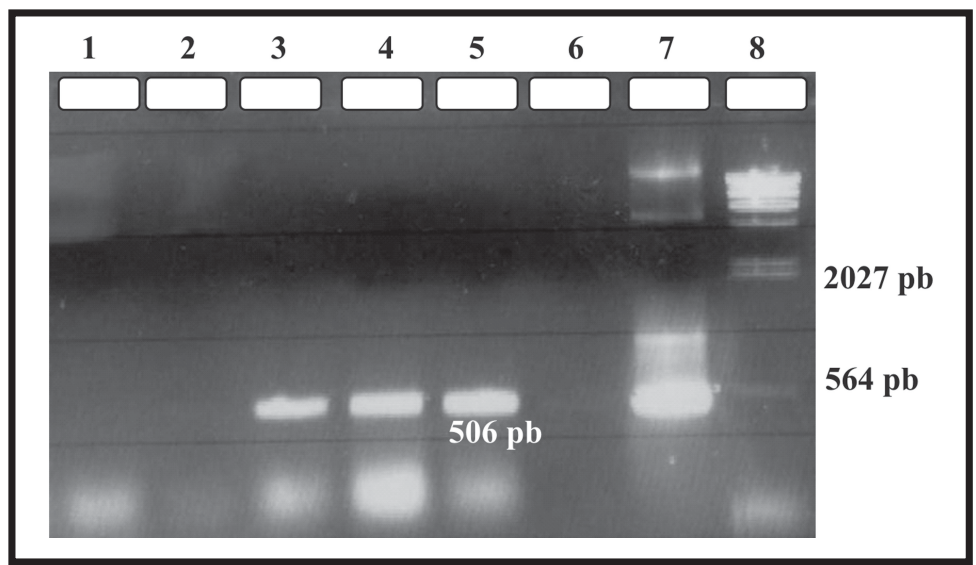

Figura 2 - Análise do produto de amplificação por eletroforese em gel de agarose 1\% $(\mathrm{m} / \mathrm{v})$. Coluna 1: RT-PCR de células HEK 293 não transfectadas. Coluna 2: RT-PCR de células HEK 293 transfectadas com o vetor recombinante (expressão transitória). Coluna 3: RT-PCR de células HEK 293 transfectadas com o vetor recombinante (expressão permanente - clone no. 7). Coluna 4: RT-PCR de células HEK 293 transfectadas com o vetor recombinante (expressão permanente - clone no. 10). Coluna 5: RT-PCR de células HEK 293 transfectadas com o vetor recombinante (expressão permanente - clone no. 12). Coluna 6: Controle negativo da reação (mistura reacional sem adição de DNA). Coluna 7: Controle positivo da reação (DNA proviral usado como template). Coluna 8: Marcador de peso molecular II (Boehring Mannhem Gmbh - Germany).

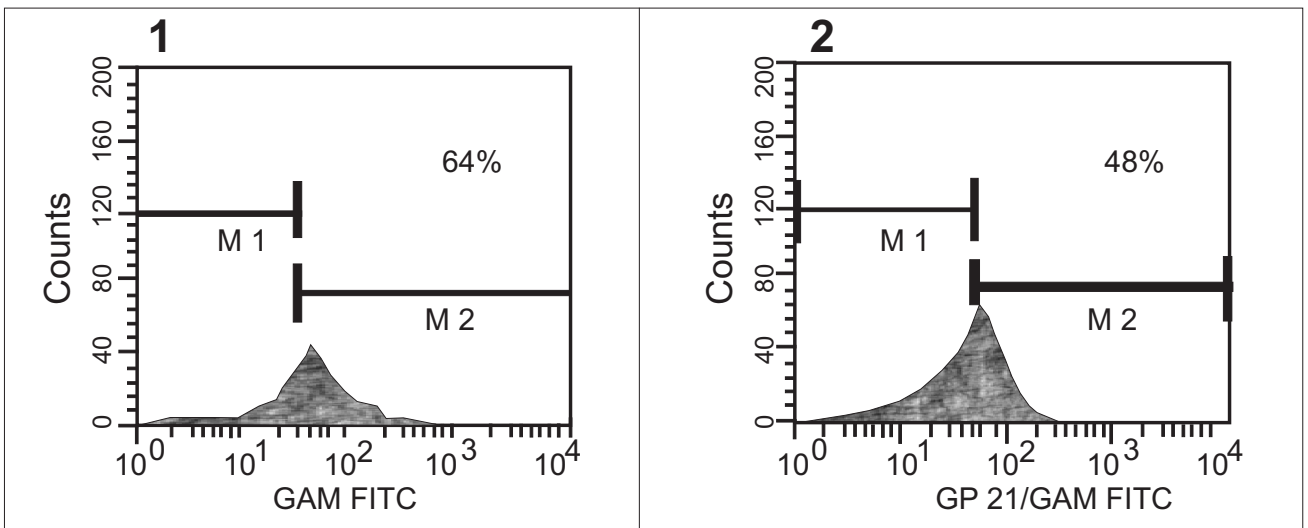

Figura 3 - Representação gráfica da análise das células transfectadas quanto a produção da gp 21 recombinante. Quadro 1: Células HEK 293 transfectadas analisadas após 48 horas do cultivo com meio DMEM suplementado, marcadas com os anticorpos primário monoclonal e secundário. Quadro 2: Células HEK 293 transfectadas analisadas após 10 dias de tratamento com antibiótico e marcadas com os anticorpos primário monoclonal e secundário.

\section{DISCUSSÃo}

A glicoproteína transmembrana é considerada uma das proteínas mais imunogênicas do HTLV-1. A obtenção de uma linhagem celular que expresse a proteína recombinante constitutivamente possibilita o estudo mais aprofundado dos mecanismos que envolvem a gp 21 com a infectividade do vírus, por meio da utilização da linhagem celular transfectada em ensaios laboratoriais de imunogenicidade e de diagnóstico. 0 fragmento codificante da gp 21 foi clonado em vetores plasmidiais e confirmado pelo seqüenciamento de nucleotídeos. A expressão da gp 21 recombinante foi possibilitada pela utilização do vetor de expressão pcDNA3.1+ sob o controle do promotor de citomegalovírus. Duas técnicas foram utilizadas para a transfecção da linhagem celular de mamífero HEK 293: lipofecção e eletroporação. A lipofecção foi a mais reprodutível, rápida e de baixo custo. A transfecção foi realizada de maneira transitória e permanente. Na expressão transitória não foi observada a presença do RNAm codificante da gp 21, provavelmente pela pouca quantidade de células utilizadas na extração do RNA total, e por se tratar de uma cultura mista onde parte das células não têm o vetor recombinante. A proteína recombinante foi detectada em $64 \%$ das células analisadas. Na transfecção permanente três clones foram analisados quanto à produção do RNAm codificante da gp 21; todos são positivos. A proteína recombinante também está sendo expressada em $48 \%$ das células do clone analisado. Como a técnica utilizada para essa análise não é quantitativa, não é possível afirmar que a expressão foi maior nas células da transfecção transitória do que na transfecção permanente. Também, porque o resultado se refere a amostragem utilizada e não ao total de células. Uma linhagem celular que expresse a proteína recombinante de maneira definitiva será estudada.

Por fim, pode-se concluir que tanto a cultura mista (expressão transitória) quanto o clone (expressão permanente) analisados demonstraram uma significativa porcentagem de células expressando a gp 21 do HTLV-1 recombinante. 


\section{REFERÊNCIAS BIBLIOGRÁFICAS}

1. Arp J, Ford CM, Palker TJ, King EE, Dekaban GA. Expression and immunogenicity of the entire human T cell leukaemia virus type I envelope protein produced in a baculovirus system. Journal of General Virology 74:211-222, 1993

2. Arp J, Levatte M, Rowe J, Perkins S, King E, Leystra-Lantz C, Foung SK, Dekaban GA. A source of glycosylated human T-cell lymphotropic virus type 1 envelope protein: expression of gp 46 by the vaccinia virus/T7 polymerase system. Journal of Virology 70: 7349-7359, 1996.

3. Chu G, Hayakawa H, Berg P. Electroporation for the efficient transfection of mammalian cells with DNA. Nucleic Acids Research 15: 1311-1326, 1987.

4. Delamarre L, Rosenberg AR, Pique C, Pham D, Dokhelar MC. A novel human T-leukemia virus type 1 cell-to-cell transmission assay permits definition of SU glycoprotein amino acids important for infectivity. Journal of Virology 71: 259-266, 1997.

5. Felgner PL, Ringold GM. Cationic liposome-mediated transfection. Nature 337:387-388, 1989.

6. Gessain A, Barin F, Vernant JC, Gout 0, Maurs L, Calender A, De The G. Antibodies to human T-lymphotropic virus type-1 in patients with tropical spastic paraparesis. Lancet 2: 407-410, 1985.

7. Graham FL, Smiley J, Russell WC, Nairn R. Characteristics of a human cell line transformed by DNA from human adenovirus type 5. Journal of General Virology 36: 59-74, 1977.

8. Hanahan D. Studies on transformation of Escherichia coli with plasmids. Journal of Molecular Biology 166: 557-580, 1983.

9. Kazanji M, Tartaglia J, Franchini G, De Thoisy B, Talarmin A, Contamin H, Gessain A, De The G. Immunogenicity and protective efficacy of recombinant human T-cell leukemia/lymphoma virus type 1 NYVAC and naked DNA vaccine candidates in squirrel monkeys (saimiri sciureus). Journal of Virology 75: 5939-5948, 2001.

10. Kuga T, Hattori S, Yoshida M, Taniguchi T. Expression of human T-cell leukemia virus type 1 envelope protein in Saccharomyces cerevisiae. Gene 44: 337-340, 1986.

11. Lillehoj EP, Alexander SS, Dubrule CJ, Wiktor S, Adams R, Tai CC, Manns A, Blattner WA. Development and evaluation of a human T-cell leukemia virus type 1 serologic confirmatory assay incorporating a recombinant envelope polypeptide. Journal of Clinical Microbioly 28: 2653-2658, 1990.

12. Mandel M, Higa A. Calcium-dependent bacteriophage DNA infection. Journal of Molecular Biology 53: 159-162, 1970.

13. Nakamura H, Hayami M, Ohta Y, Ishikawa K, Tsujimoto H, Kiyokawa T, Yoshida M, Sasagawa A, Honjo S. Protection of cynomolgus monkeys against infection by human T-cell leukemia virus type-1 by immunization with viral env gene products produced in Escherichia coli. International Journal of Cancer 40: 403-407, 1987.

14. Nyunoya H, Ogura T, Kikuchi M, Iwamoto H, Yamashita K, Maekawa M, Takebe Y, Miyamura K, Yamazaki S, Shimotohno K. Expression of HTLV-I envelope protein fused to hydrophobic amino-terminal peptide of baculovirus polyhedrin in insect cells and its application for serological assays. AIDS Research and Human Retroviruses 6:1311-1321, 1990.

15. Seiki M, Hattori S, Hirayama Y, Yoshida M. Human adult T-cell leukemia virus: complete nucleotide sequence of the provirus genome integrated in leukemia cell DNA. Proceedings of the National Academy of Sciences USA 80: 3618-3622, 1983.

16. Takatsuki K. Topics in hematology. In: Proceedings of the 16th International Congress of Hematology, Kyoto p.73-77, 1976.

17. Tallet B, Astier-Gin T, Castroviejo M, SantarelliX. One-step chromatographic purification procedure of a his-tag recombinant carboxyl half part of the HTLV-I surface envelope glycoprotein overexpressed in Escherichia coli as a secreted form. Journal of Chromatography B: Biomedical Sciences and Applications 753: 17-22, 2001. 